\title{
ENTREPENEURSHIP EDUCATION THROUGH PROJECT BASED LEARNING FOR 3RD GRADE STUDENT OF KARENG KIDUL ELEMENTARY SCHOOL PROBOLINGGO
}

\author{
Suharti \& Rifqi Riva Amalia \\ suharti.karengkidul@gmail.com \\ SDN Kareng Kidul \\ Kecamatan Wonomerto \\ Kabupaten Probolinggo
}

\begin{abstract}
Indonesia needs more entrepeneurs to increase economic growth, and income percapita as developed country such as United States and Japan. One of strategy that can be done is increase entrepenur by entrepeneurship education from young age. The aim of this paper is to show how to internalise entrepeneurship character into third grade student in Kareng Kidul Public Elementary School, Wonomerto, Probolinggo. Using Project Based Learning (PjBL), this study conduct two cycles of classroom action research. In the end of second cycle, there is an increased understanding about entrepeneurship and entrepeneurship character can be internalized into students mind. Up to the level, students change their dream to become an entrepeneur.
\end{abstract}

Keywords: entrepeneurship, project based learning, classroom action research.

\section{PENDIDIKAN KEWIRAUSAHAAN MELALUI PROJECT BASED LEARNING UNTUK KELAS 3 SDN KARENG KIDUL KEC. WONOMERTO KAB. PROBOLINGGO}

\begin{abstract}
Abstrak: Indonesia membutuhkan lebih banyak pengusaha untuk mendorong pertumbuhan ekonomi dan pendapatan per kapita sebagaimana negara maju seperti Amerika Serikat dan Jepang. Salah satu upayanya dengan meningkatkan pengusaha melalui pendidikan kewirausahaan sejak dini. Penelitian ini dilakukan untuk mencari cara untuk menginternalisasi sifat-sifat pengusaha kepada siswa kelas 3 SDN Kareng Kidul, Kecamatan Wonomerto, Kabupaten Probolinggo dengan model pembelajaran Project Based Learning ( $\mathrm{PjBL}$ ). Penelitian ini adalah penelitian tindakan kelas dengan dua siklus. Hasil penelitian menunjukkan ada peningkatan pemahaman kewirausahaan dan peningkatan jumlah anak yang terinternalisasi sifatsifat pengusaha melalui model pembelajaran PjBL sampai ada tataran siswa mengubah cita-citanya menjadi pengusaha.
\end{abstract}

Kata kunci: Kewirausahaan, PjBL, PTK. 
Suharti, Rifqi, Pendidikan Kewirausahaan Melalui Project...

\section{PENDAHULUAN}

Jumlah pengusaha di Indonesia masih jauh dari standar negara maju. Menurut data BPS (2017), saat ini rasio pengusaha di Indonesia dengan jumlah penduduknya hanya 3,1 persen. Sedangkan standar yang dimiliki negara maju, rasio pengusaha terhadap jumlah penduduk total mencapai 14 persen.

Padahal, peran kewirausahaan dalam kemuajuan sebuah negara sangat krusial, sebab kehadiran kelompok wirausaha dapat membuka lapangan kerja, menaikkan kesejahteraan dan pendapatan per-kapita, juga dapat menurunkan pengangguran (Bawuah, et al., 2006 dalam Urban, 2010). Dalam buku The Achieving Society (1961), David McClelland menyatakan bahwa sebuah negara akan dapat mencapai kemakmuran apabila memiliki jumlah wirausahawan setidaknya mencapai $2 \%$ dari total populasi. Indonesia memang sudah melampaui angka 2 persen tersebut, namun masih jauh tertinggal dari negara-negara lain di ASEAN. Malaysia, Singapura dan Thailand memiliki jumlah pengusaha sebsar 4\% dari penduduk total (Okezone.com, 2018).

Karena itu, butuh usaha ekstra untuk mengejar ketertinggalan ini dengan menumbuhkan wirausahawan baru. Pemerintah Indonesia sejak era Presiden Soeharto telah berupaya memasyarakatkan kewirusahaan. Salah satunya melalui penerbitan Instruksi Presiden Nomor 4 Tahun 1995 tentang Gerakan Nasional Memasyarakatkan dan Membudayakan Kewirausahaan, mengamanatkan kepada seluruh masyarakat dan bangsa Indonesia untuk mengembangkan program-program kewirausahaan. Hingga saat ini upaya tersebut masih berlangsung dan diadaptasi ke dalam berbagai bentuk.

Menurut Mulyani (2011) kewirausahaan adalah kewirausahaan adalah nilai-nilai yang membentuk karakter dan perilaku seseorang yang selalu kreatif, berdaya, bercipta, berkarya dan berusaha dalam rangka meningkatkan pendapatan dalam kegiatan usahanya.

Konsep kewirausahaan tersebut, dalam dunia pendidikan bisa diajarkan sejak sekolah dasar hingga perguruan tinggi. Pendidikan kewirausahaan yang dikembangkan di sekolah umumnya menerapkan prinip-prinsip dan metodologi ke arah pembentukan keterampilan hidup atau life skill peserta didik melalui kurikulum yang dikembangkan sekolah tersebut. Internalisasi nilai-nilai wirausaha merupakan bagian dari pendidikan karakter yang menjadi tulang punggung penerapan Kurikulum 2013.

Pendidikan karakter yang ditekankan penerapannya pada Kurikulum 2013 dapat diimplementasikan melalui pelajaran ekstrakurikuler, maupuan terintegrasi langsung melalui pembelajaran dalam setiap mata pelajaran (Mulyani dkk., 2010).

Dalam hal kegiatan ekstrakurikuler, guru dapat membantu pengembangan

peserta didik melalui kegiatan khusus di luar mata pelajaran untuk mengimplementasikan pendidikan kewirausahaan. Kegiatan ini secara khusus diselenggarakan oleh guru atau tenaga kependidikan untuk mengembangkan potensi, bakat dan minat sesuai kebutuhan dan kemampuan peserta didik. Umumnya kegiatan 
Suharti, Rifqi, Pendidikan Kewirausahaan Melalui Project...

kewirausahaan yang diselenggarakan melalui ekstrakurikuler bersifat tidak wajib bagi seluruh peserta didik.

Sedangkan pendidikan kewirausahaan yang diintegrasikan dalam mata pelajaran dapat dilakukan dengan memberikan materi yang berkaitan dengan norma atau nilainilai pada setiap mata pelajaran secara eksplisit dan dikaitkan dengan konteks kehidupan sehari-hari. Dengan demikian, pembelajaran yang berwawasan pendidikan kewirausahaan tidak hanya pada tataran kognitif, tetapi menyentuh pada internalisasi dan pengamalan nyata dalam kehidupan peserta didik sehari-hari di masyarakat (Mulyani, 2011)

Menurut Saroni (2013), kompetensi kewirausahaan yang diberikan kepada peserta didik menjadikan mereka sebagai sosok efektif dalam kehidupan. Jika peserta didik mempunyai keterampilan berwirausaha, mereka dapat menjadi pribadi yang lebih bertanggung jawab atas kehidupannya secara pribadi maupun sosial. Kewirausahaan juga menumbuhkan rasa percaya diri siswa didik serta menambah keterampilan hidup (life skill), mengingat dalam pendidikan kewirausahaan, siswa juga diajari untuk berani mengambil risiko ketika usaha mereka menemui jalan buntu.

Pendidikan kewirausahaan juga bisa menjadi salah satu upaya untuk menumbuhkan karakter baik dalam diri siswa. Pengembangan jiwa kewirausahaan merupakan bagian dari pengembangan karakter yang dapat mengubah pola pikir peserta didik yang selalu berorientasi menjadi karyawan diubah untuk mencari karyawan (Mulyani dkk., 2010)

Pendidikan kewirausahaan dalam sekolah, setidaknya harus mampu menjadikan anak memiliki bibit sifat-sifat kewirausahaan dalam dirinya. Sehingga jika sifat kewirausahaan itu dipupuk sejak anak usia sekolah, diharapkan pada saat dewasa, mereka telah siap menjadi pengusaha yang sesungguhnya.

Geffrey G. Meredith dalam Suharyadi (2007) mengatakan bahwa ciri-ciri seorang pengusaha terdiri dari beberapa sifat berikut: 1) Percaya diri yang merupakan sikap dan keyakinan untuk memulai, melakukan dan menyelesaikan tugas atau pekerjaan yang dihadapi. 2) Berorientasi tugas dan hasil, artinya pengusaha harus melakukan tindakan yang mengarah pada usaha untuk mencapai tujuan yang telah ditentukan. 3) Berani mengambil risiko, karena setiap proses bisnis memiliki risiko untung-rugi sehingga wirausahawan harus mampu memperhitungkan peluang kegagalan dan berusaha memperkecil risiko kerugian. 4) Kepemimpinan atau leadership dalam hal ini diartikan sebagai kemampuan memimpin orang lain atau sebuah team untuk mengantisipasi setiap perubahan. 5) Keorisinilian, di mana pengusaha harus mampu menciptakan sesuatu yang baru dan berbeda. 6) Berorientasi Masa Depan, seorang pengusaha memiliki pandangan jauh ke depan dan rajin mencari peluang usaha baru yang berorientasi masa depan.

Sifat kewirausahaan tersebut dapat dilatih sejak anak berada dalam pengasuhan orang tua. Sebagaimana yang dikatakan Muhammad Jufri dan Wirawan dalam bukunya 
Suharti, Rifqi, Pendidikan Kewirausahaan Melalui Project...

Internalisasi Jiwa Kewirausahaan Pada Anak (2014). Jufri dan Wirawan menyebutkan, untuk menciptakan jiwa kewirausahaan yang baik, proses internalisasi tidak hanya dimulai ketika anak telah memasuki usia sekolah, tetapi dimulai seiring perkembangan anak. Sebelum anak memasuki usia sekolah, proses internalisasi kewirausahaan bisa dilakukan melalui pendidikan oleh orang tua dan keluarganya yang lain.

Proses ini bisa dilanjutkan oleh guru ketika anak memasuki usia sekolah melalui beragam cara. Baik melalui pengenalan kewirausahaan melalui proses pembelajaran di kelas maupun pembelajaran di luar kelas. Dalam proses pembelajaran di dalam kelas, guru dapat memanfaatkan model pembelajaran project based learning (PjBL) untuk mengenalkan konsep kewirausahaan.

Penggunaan model $\mathrm{PjBL}$ atau pembelajaran berbasis proyek sangat tepat dilakukan, karena membuat peserta didik ikut berperan aktif dalam pembelajaran dan berhasil memecahkan masalah-masalah yang kompleks. Project Based Learning adalah model pembelajaran yang mengunakan proyek/ kegiatan sebagai proses pembelajaran untuk mencapai kompetensi sikap, pengetahuan, dan keterampilan (Setiawan, dkk., 2017). Pembelajaran lebih ditekankan pada aktivitas peserta didik untuk menghasilkan produk dengan menerapkan keterampilannya untuk melakukan kegiatan meneliti, menganalisis, membuat, sampai dengan mempresentasikan produk pembelajarannya berdasarkan pengalaman di dunia nyata.

Dalam pembelajaran di dalam kelas, implementasi Project Based Learning melalui penggunaan proyek atau kegiatan sebagai media pembelajaran. Materi pelajaran disampaikan dengan cara memberi kesempatan pada sisiwa untuk merancang sebuah proyek mulai dari awal sampai eksekusi akhir. Menurut The George Lucas Educational Foundation yang dikutip Sabar Nurohman (2007), langkah langkah PjBL dimulai dengan pendidik yang mengajukan pertanyaan dasar untuk memancing siswa melakukan aktivitas atau proyek. Kemudian dilanjutkan dengan pembuatan desain rencana proyek oleh siswa yang didampingi guru. Dari desain tersebut, siswa kemudian menyusun jadwal pelaksanaan kegiatan pembelajaran dari awal mula proyek hingga akhir. Guru dapat mengarahkan peseta didik jik amereka membuat rencana yang tidak berhubungan dengan proyek. Selanjutnya guru bertanggungjawab memantau kegiatan siswa selama menyelesaikan proyek untuk mengetahui kemajuan proyek sekaligus mengantisipasi hambatan yang mungkin akan dihadapi siswa. Setelah proyek dilakukan, guru menilai pekerjaan peserta didik sesuai standar ketercapaian dan hasil pembelajaran digunakan sebagai bahan pertimbangan dalam menyusun strategi pembelajaran berikutnya.

Dengan menggunakan model pembelajaran Project Based Learning ini siswa diharapkan mendapatkan motivasi berlebih, memiliki kemampuan memecahkan masalah, bekerjasama dengan orang lain dan belajar mengatur atau memanajeri sebuah kegiatan dan orang yang bekerja bersamanya. 
Suharti, Rifqi, Pendidikan Kewirausahaan Melalui Project...

Pada siswa kelas 3 sekolah dasar, implementasi pelaksanaan Project Based Learning dapat dilakukan pada pembelajaran Tema 2, Perkembangan Teknologi subtema 4, kegiatan berbasis proyek.

\section{METODE}

Penelitian ini adalah merupakan bagian dari action research atau penelitian tindakan dengan setting sebuah kelas. Dalam pelaksanaannya, kedua peneliti berkolaborasi dalam melakukan penelitian di dalam kelas. Penelitian ini dilaksanakan di Kelas 3 SDN Kareng Kidul, Kecamatan Wonomerto, Kabupaten Probolinggo pada akhir semester ganjil tahun ajaran 2017/2018 lalu. Tepatnya, pada saat kegiatan pembelajaran memasuki pembelajaran pada Tema 2, Perkembangan Teknologi dan subtema 4, kegiatan berbasis proyek.

Wali kelas 3, Suharti S.Pd bertindak sebagai ketua regu dan dibantu oleh Rifqi Riva Amalia sebagai anggota. Subyek penelitian ini berjumlah 20 anak yang terdiri dari 11 anak perempuan dan 9 anak laki-laki.

Penelitian ini menggunakan metode Penelitian Tindakan Kelas (PTK) yang dilakukan selama 2 siklus. Setiap siklusnya dilakukan dua kali pertemuan. Teknik pengumpulan data yang digunakan adalah: 1) observasi; 2) wawancara; dan 3) dokumentasi. Penelitian ini terdiri dari empat tahapan dasar yaitu perencanaan (planning), pelaksanaan (acting), pengamatan (observing) dan refleksi (reflecting). Analisis penelitian ini adalah analisis naratif kualitatif di mana dalam penelitian ini selain penyajian hasil berupa data maupun angka, peneliti juga menjelaskan secara naratif mengenai perubahan pola perilaku dan pendapat siswa terhadap nilai-nilai kewirausahaan dengan menerapkan model pembelajaran Project Based Learning (PjBL).

Pada penelitian tindakan kelas ini data yang dikumpulkan adalah data hasil pengamatan pada siswa sebelum pelaksanaan proyek, pada saat pelaksanaan proyek dan sesudah pelaksanaan proyek.

Pemahaman konsep kewirausahaan dinyatakan berhasil jika lebih dari $80 \%$ siswa memahami arti kewirausahaan dan bisa memberikan contoh bentuk kegiatan yang berorientasi wirausaha. Proses internalisasi nilai kewirausahaan dinyatakan berhasil jika siswa mencapai perubahan sikap sebesar 70 persen di akhir siklus 2 .

Dalam proses pembuatan "duk-sunduk singkong" siswa harus melalui tahap berikut ini:
a. membuat rencana bisnis dan survei
b. membuat rencana penjualan
c. membuat kemasan produk
d. mempraktikkan penjualan "duk-sunduk singkong" dengan percaya diri
e. menceritaka pengalamannya berjualan tempe dengan percaya diri
f. menuliskan kegiatan yang telah dilakukannya pada buku jurnal 
Suharti, Rifqi, Pendidikan Kewirausahaan Melalui Project...

ketuntasan belajar siswa dinyatakan tuntas jika siswa mampu mengikuti 80 persen seluruh kegiatan dengan baik.

\section{HASIL}

Penerapan model pembelajaran Project Based Learning (PjBL) di kelas 3 SDN Kareng Kidul, Kecamatan Wonomerto dilakukan pada saat pembelajaran sampai pada Tema 2, Perkembangan Teknologi di subtema 4, kegiatan berbasis proyek. Wali kelas mengajak siswa untuk membuat makanan ringan yang populer di lokasi sekitar sekolah, yaitu "Duk-sunduk" yang berbahan dasar singkong.

Berikut ini paparan data dari kegiatan penelitian tindakan kelas pada anak kelas 3 dalam pendidikan kewirausahaan melalui penerapan model pembelajaran Project Based Learning (PjBL).

\section{Data Pra Tindakan}

Berdasarkan obervasi sebelum tindakan yang dilakukan peneliti di kelas 3 SDN Kareng Kidul, Kecamatan Wonomerto, Kabupaten Probolinggo, siswa belum memahami konsep wirausaha dan internalisasi nilai-nilai kewirausahaan dalam diri siswa masih rendah. Dari 20 anak, hanya ada 9 anak atau $45 \%$ yang memahami mengenai konsep wirausaha sedangkan sisanya, 11 anak atau 55\% siswa menjawab tidak tahu atau mengatakan jawaban tidak benar. Hal ini disebabkan karena selama ini siswa belum dikenalkan mengenai konsep wirausaha dan bagaimana proses menjalankan usaha.

Dari hasil observasi diperlukan tindakan agar anak memahami konsep kewirausahaan dan dapat meningkatkan internalisasi sifat-sifat wirausaha dalam dirinya. Maka guru mengenalkan proses pembuatan 'duk-sunduk singkong" sebagai bagian dari penerapan model pembelajaran Project Based Learning (PjBL) sekaligus mengenalkan konsep kewirausahaan pada siswa kelas 3 SDN Kareng Kidul, Kecamatan Wonomerto, Kabupaten Probolinggo.

\section{Temuan Siklus I}

Pada siklus I dikemukakan beberapa temuan penelitian saat kegiatan pembelajaran dengan menerapkan model pembelajaran PjBL sebagai sarana pendidikan kewirausahaan. Penerapan $\mathrm{PjBL}$ dapat meningkatkan pemahaman siswa mengenai kewirausahaan dan internalisasi sifat-sifat pengusaha menunjukkan perubahan. Disamping itu, menumbuhkan semangat belajar siswa yang ditunjukkan dengan tingginya antusiasme siswa ketika guru menjelaskan mengenai kegiatan yang akan mereka lakukan di kelas.

Kekurangan yang terjadi pasa siklus I adalah guru belum mampu menguasai kelas. Siswa didik masih cenderung ramai dan mengajukan pertanyaan yang tidak ada hubungannya dengan pembelajaran. Selain itu banyak siswa yang ragu-ragu dalam melaksanakan kegiatan pembelajaran dan terlihat bingung. 
Suharti, Rifqi, Pendidikan Kewirausahaan Melalui Project...

Namun, penunjukan ketua kelompok yang tepat membantu guru dalam menjelaskan kegiatan yang akan dilaksanakan. Sehingga di akhir siklus I siswa dapat melaksanakan kegiatan perencanaan pembuatan produk duk sunduk dengan baik sekaligus mampu merencanakan pemasarannya.

\section{Temuan Siklus II}

Pada siklus II kegiatan pembelajaran berjalan dengan lebih baik karena seluruh siswa memahami tujuan pembelajaran dengan baik. Siswa juga telah melakukan persiapan pembelajaran lebih baik.

Guru hanya melakukan beberapa kali tindakan untuk meluruskan pemahaman siswa. Pemahaman siswa terhadap konsep wirausaha juga mengalami perbaikan dan proses internalisai nilai-nilai kewirausahaan mengalami peningkatan. Pada akhir siklus II ini ketuntasan belajar siswa mencapai 80 persen, sehingga hasil pembelajaran sudah memenuhi standar yang ditetapkan.

Adanya anak yang belum tuntas pada siklus II dalam kegiatan pembuatan duksunduk, dikarenakan anak terebut sakit dan rendahnya kemampuan berfikir si anak, sehingga proses internalisasi nilai-nilai kewirausahaan tidak berjalan dengan baik.

Temuan Lengkap

Berdasarkan hasil analisis data pada penelitian tindakan kelas di pra siklus, siklus I dan siklus II, disajikan secara lengkap dalam tabel-tabel di bawah ini.

Tabel 1. Persentase peserta didik yang memahami mengenai konsep kewirausahaan

\begin{tabular}{|c|c|c|c|}
\hline Aspek Penilaian & Pra Tindakan & Siklus I & Siklus II \\
\hline Arti Wirausaha & $45 \%$ siswa & $90 \%$ siswa & $90 \%$ siswa \\
\hline $\begin{array}{c}\text { Bentuk Kegiatan } \\
\text { Wirausaha }\end{array}$ & $30 \%$ siswa & $80 \%$ siswa & $90 \%$ siswa \\
\hline
\end{tabular}

Tabel 2. Persentase peserta didik yang memiliki sifat-sifat wirausaha

\begin{tabular}{|l|l|l|l|}
\hline Aspek Penilaian & Pra Tindakan & Siklus I & Siklus II \\
\hline Percaya Diri & $20 \%$ siswa & $50 \%$ siswa & $80 \%$ siswa \\
Berorientasi Hasil & $25 \%$ siswa & $50 \%$ siswa & $75 \%$ siswa \\
Berani Mengambil Risiko & $20 \%$ siswa & $45 \%$ siswa & $70 \%$ siswa \\
Kepemimpinan & $15 \%$ siswa & $60 \%$ siswa & $65 \%$ siswa \\
Keorisinilan & $10 \%$ siswa & $45 \%$ siswa & $80 \%$ siswa \\
Berorientasi Masa Depan & $15 \%$ siswa & $40 \%$ siswa & $90 \%$ siswa \\
\hline
\end{tabular}

\section{PEMBAHASAN}

Pendidikan kewirausahaan yang diterapkan pada siswa kelas 3 SDN Kareng Kidul, Kecamatan Wonomerto, Kabupaten Probolinggo dilaksanakan melalui penerapan model pembelajaran Project Based Learning, pembuatan dan penjualan 'duk-sunduk singkong" makanan ringan berbentuk bola-bola yang terbuat dari singkong.

Pada pra tindakan, peneliti melakukan observasi dan wawancara kepada subyek penelitian mengenai konsep wirausaha yang terdiri dari pengertian wirausaha dan 
Suharti, Rifqi, Pendidikan Kewirausahaan Melalui Project...

contoh kegiatan wirausaha. Hasilnya hanya ada 9 anak yang memahami arti wirausaha dan 6 anak yang dapat menyebutkan contoh kegiatan wirausaha dengan benar. Sedangkan sisanya menjawab salah atau tidak tahu.

Mengukur internalisasi nilai kewirausahaan pada peserta didik dilakukan dengan menggunakan sifat-sifat pengusaha menurut Geffrey Meredith sebagai tolak ukur. Hasilnya, hanya ada $20 \%$ siswa yang percaya diri dan berani mengambil risiko dan $15 \%$ siswa yang berani menjadi pemimpin bagi siswa lain (selengkapnya lihat tabel 2).

Pada siklus I guru mengajak siswa untuk merencanakan proyek berupa pembuatan dan penjualan makanan ringan. Setelah berdiskusi bersama dengan seluruh peserta didik, disepakati untuk membuat duk-sunduk singkong karena bahan yang mudah didapat dan seluruh siswa mengetahui makanan tersebut.

Siswa dibagi ke dalam 4 kelompok. Setiap kelompok merencanakan produk yang akan dibuat, kemasan serta strategi pemasaran. Pada akhir siklus I hampir seluruh siswa memahami dengan baik mengenai konsep wirausaha dan mampu menjelaskan dengan bahasa mereka sendiri. Peserta didik juga mampu memberikan contoh bentuk kegiatan wirausaha yang ada di sekitar mereka.

Sifat-sifat pengusaha yang terinternalisasi dalam sikap mulai nampak dalam pelaksanaan pembelajaran. 10 mulai percaya diri mengemukakan pendapatnya. Jumlah ini naik dari yang semula hanya 5 anak atau 25\% dari total siswa kelas 3 (lihat tabel 2).

Sifat "berorientasi hasil" juga mulai terbentuk pada beberapa anak dalam kelompok yang berbeda. Upaya guru untuk mengajak siswa merencanakan pembuatan makanan ringan membangkitkan semangat bersaing sehingga semakin banyak siswa fokus pada tindakan untuk menyelesaikan tugasnya.

Keberanian mengambil risiko tercermin dalam keputusan beberapa siswa yang mengusulkan untuk membuat duk-sunduk lebih banyak agar memperoleh hasil penjualan lebih besar. Beberapa anak juga mengusulkan penambahan toping atau bahan taburan di atas duk-sunduk. Hal ini dinilai sebagai adanya sifat keorisinilan.

Di akhir siklus I ada 8 siswa yang mengubah cita-citanya dari semula menjadi karyawan atau guru, kini menjadi pengusaha atau pedagang.

Pada siklus II, guru mengajak siswa melaksanakan perencanaan yang telah dibuat sebelumnya. Peralatan dan bahan telah disediakan oleh guru dan pihak sekolah, sehingga siswa hanya perlu praktik membuat, mengemas lalu memasarkan produknya pada warga sekolah.

Dalam pelaksanaan di siklus II juga nampak perubahan perilaku siswa. Semakin banyak siswa yang sifat-sifat pengusahanya terinternalisasi dengan baik. Ada $80 \%$ anak atau 16 anak yang kini percaya diri mengungkapkan pendapatnya setelah berakhirnya siklus II. Selain itu setiap kelompok menciptakan kemasan yang berbeda. Ada yang dari kantong plastik, daun pisang, kertas minyak dan kemasan mika. Menariknya, setiap kemasan memiliki identitas kelompok berupa gambar yang mewakili mereka. 
Suharti, Rifqi, Pendidikan Kewirausahaan Melalui Project...

Pembuatan kemasan ini menunjukkan sifat keorisinilan telah terinternalisasi kepada beberapa anak.

Kegiatan pembelajaran dengan PjBL ini pad akhir siklus II juga mengubah persepsi anak mengenai cita-cita sebagai pengusaha. Ada 18 anak yang menjadikan profesi pengusaha atau pedagang sebagai cita-cita utama mereka kelak di masa depan.

Dalam dua siklus, ketuntasan belajar siswa mencapai 90 persen. Artinya dari 20 siswa kelas 3 SDN Kareng Kidul, 18 anak mengikuti setiap tahapan pembelajaran dengan model pembelajaran Project Based Learning ini dengan baik. Satu anak tidak tuntas karena sakit dan anak lain dinyatakan tidak tuntas karena tidak mengikuti tahapan kegiatan karena kurangnya pemahaman.

\section{SIMPULAN}

Berdasarkan hasil penelitian dan pembahasan, maka peneliti dapat menarik kesimpulan sebagai berikut:

1. Pendidikan Kewirausahaan pada siswa Kelas 3 SDN Kareng Kidul, Kecamatan Wonomerto, Kabupaten Probolinggo dapat dilaksanakan dengan memanfaatkan model pembelajaran Project Based Learning.

2. Pelaksanaan proyek pembuatan dan penjualan duk-sunduk singkong dalam pelaksanaan model pembelajaran PjBL di kelas 3 SDN Kareng Kidul, Kecamatan Wonomerto, Kabupaten Probolinggo mampu meningkatan pemahaman kewirausahaan dan proses internalisasi sifat-sifat pengusaha pada siswa didik.

\section{DAFTAR RUJUKAN}

Jufri, M. \& Wirawan, H. 2014. Internalisasi Jiwa Kewirausahaan Pada Anak. Jakarta: Kencana Perenda Media Group.

McClelland, D. C. 1961. The Achieving Society. New Jersey : D. Van Nostrand Company, Inc

Mulyani, Endang., dkk. 2010. Pengembangan Pendidikan Kewirausahaan. Jakarta: Pusat Kurikulum, Badan Penelitian dan Pengembangan Kementerian Pendidikan Nasional.

Mulyani, Endang. 2011. Model Pendidikan Kewirausahaan di Pendidikan Dasar Menengah. Jurnal Ekonomi dan Pendidikan. Vol. 8 No. 1.

Nurohman, S. 2007. Pendekatan Project Based Learning Sebagai Upaya Internalisasi Scientific Method bagi Mahasiswa Calon Guru Fisika. Yogyakarta: Universitas Negeri Yogyakarta.

Saroni, M. 2013. Mendidik \& Melatih Entrepeneur Muda: Membuka Kesadaran atas Pentingnya Kewirausahaan bagi Anak Didik. Yogyakarta: Ar Ruzz Media.

Suharyadi, dkk. (2007). Kewirausahaan Membangun Usaha Sukses Sejak Usia Muda. Jakarta: Salemba Empat

Urban, B. 2010. Frontiers in Entrepeneurship. Berlin: Springer. 